\title{
TESTER BATERAI SEDERHANA BERBASIS MIKROKONTROLER ATMEGA8535 UNTUK KARAKTERISASI PENGISIAN-PENGOSONGAN BATERAI SEL TUNGGAL
}

\author{
Syamsudin Nur Wahid ${ }^{1}$, Muhammad Miftahul Munir², Khairurrijal ${ }^{2}$ \\ 1) Jurusan Teknik Elektro, Fakultas Teknik \\ Universitas Islam Balitar Blitar \\ Jl. Majapahit no.4 Blitar \\ 2) Jurusan Fisika, Faultas MIPA \\ Institut Teknologi Bandung \\ Jalan Ganesa 10, Bandung 40132 \\ Corresponding author: Snowhaatt@gmail.com
}

\begin{abstract}
Abstrak
Penguji baterai berbasis mikrokontroler yang dibuat dari programmable load dan programmable power supply telah dikembangkan untuk mengkarakterisasi pola pengisian dan pengosongan baterai sel tunggal. Fluke 5100B dan Fluke 8808A telah digunakan untuk mengkalibrasi baterai tester. Untuk mengetahui kemampuan baterai tester, telah digunakan baterai NiMH dan LiPo sebagai piranti yang diuji dan datasheetnya sebagai referensi. Pengkuran menunjukkan bahwa karakteristik arus dan tegangan yang terukur telah sesuai dengan pola pengisian-pengosongan baterai pada umumnya dari datasheet.
\end{abstract}

Kata kunci: karakterisasi baterai, pengisian-pengosongan, mikrokontroler

\section{PENDAHULUAN}

Baterai merupakan perangkat yang sangat dibutuhkan untuk kebanyakan peralatan elektronik saat ini [1]. Selain sebagai sumber tenaga bagi devais portabel [2] [3] [4], juga sebagai penyimpan energi pada pembangkit listrik [5]. Penelitian selalu dilakukan untuk meningkatkan kemampuan baterai [6] [7] [8] [9] [10]. Berbagai pengujian diperlukan untuk mengetahui kemampuan baterai [11] [12] [13]. Untuk mendukung hal tersebut diperlukan baterai tester. Baterai tester utamanya digunakan untuk mengkarakterisai arus dan tegangan baterai, selanjutnya dapat ditentukan kapasitas, energi dan hambatan dalam baterai [14].

Paper ini membahas pengembangan baterai tester berbasis mikrokontroler ATmega8535 [15] sebagai pengendali utama. Sistem ini dapat mengukur arus pada rentang 0.002-2 A dan tegangan 0.005-5 volt. Baterai NiMH dan LiPo telah dikaraktersasi dengan metode charging-discharging menggunakan perangkat ini untuk melihatnya sesuai dengan datasheet.

\section{HARDWARE DAN SOFTWARE BATERAI TESTER}

Sistem karakterisasi baterai metode charging-discharging berbasis mikrokontroler secara umum ditunjukkan pada Gambar 1. Baterai dikosongkan dan diisi hingga penuh secara bergantian. Baterai dikosongkan dengan menghubungkannya dengan resistor dan diisi dengan suatu charger yang arusnya diatur. Selama pengisian dan pengosongan baterai selalu dipantau arus dan tegangannya. 
Charger dan hambatan merupakan perangkat yang dapat membatasi arus yang melewatinya. Untuk itu digunakan Programmable Power Supply (PPS) sebagai charger dan Programmable Load (PL) sebagai hambatan. PPS dan PL tersusun dari regulator boost sebagai komponen utama. PL digunakan saat pengosongan, maka baterai dihubungkan paralel dengan regulator boost dan tanpa power supply. PPS untuk pengisian, sehingga baterai dihubungkan serial dengan regulator boost dan memerlukan sumber daya 9 volt.

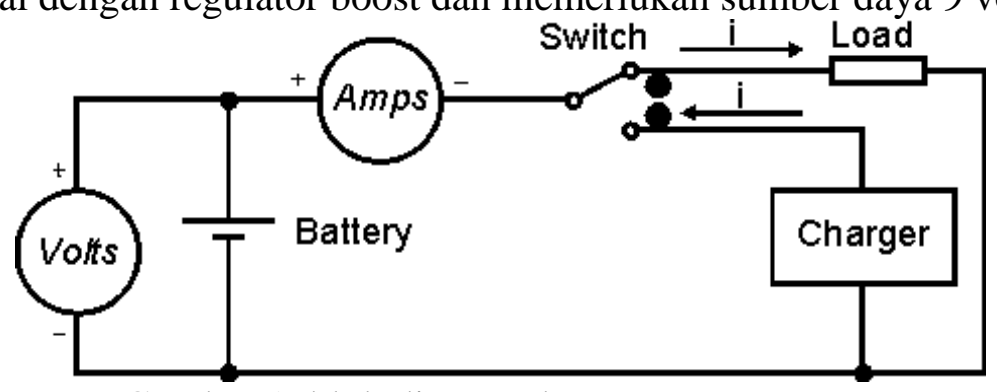

Gambar 1. blok diagram battery tester umum

Boost regulator umumnya digunakan pada sistem manajemen daya [16] dan aplikasi baterai [17]. Boost regulator terdiri dari MOSFET IRFP250, sebuah induktor $4 \mu \mathrm{H}$ dan kapasitor $1000 \mu \mathrm{F}$ dengan rangkaian yang ditunjukkan pada gambar 2 . Arus yang melalui regulator boost dikontrol oleh sinyal pwm $2.5 \mathrm{kHz}$ dari mikrokontroler ATMega 8535. Amperemeter dihubungkan secara serial dengan regulator boost, baik pada PL maupun PPS.

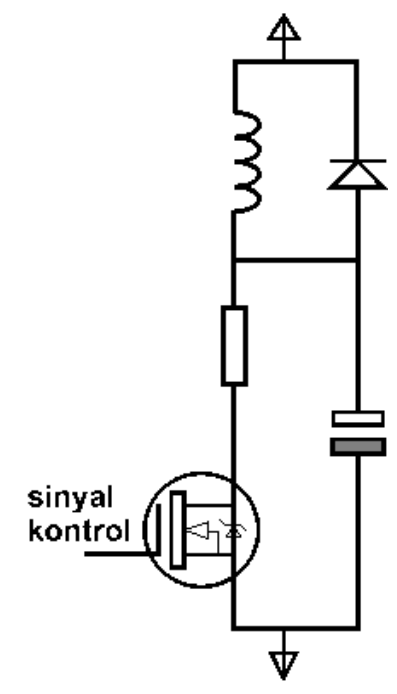

Gambar 2. Skema rangkaian dari Boost Regulator

Gambar 3 menunjukkan diagram blok pada pengolah sinyal analog untuk amperemeter dan voltmeter yang terdiri dari buffer dan rangkaian pengkondisi sinyal. Sinyal tegangan baterai harus melewati buffer terlebih dahulu sebelum masuk ADC mikrokontroler untuk meminimalisir arus bocor. Pengkondisi sinyal untuk amperemeter berupa penguat tak membalik dengan tapis lolos rendah menggunakan LM324 [18]. Arus sebanding dengan tegagan pada sensing resistor $0.1 \Omega$ yang dikuatkan 10 kali oleh pengkondisi sinyal. Keluaran amperemeter maupun voltmeter dihubungkan secara langsung pada mikrokontroler melalui port ADC 10-bit. Data dari mikrokontroler akhirnya dikirimkan ke komputer melalui port komunikasi serial. 


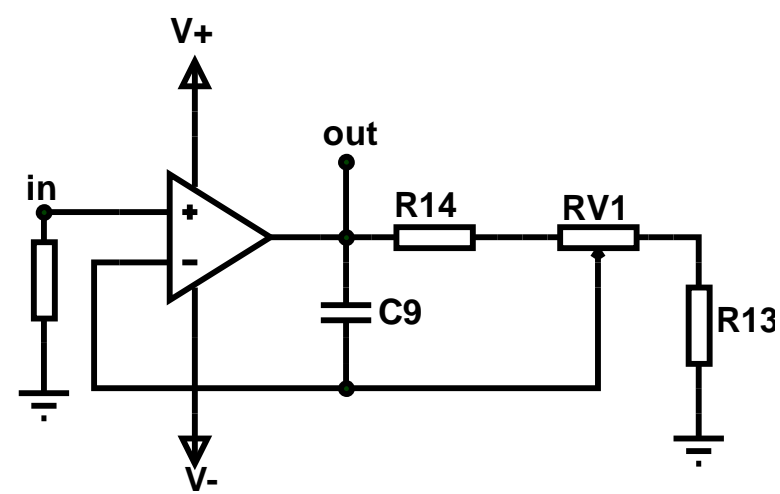

Gambar 3. skema rangkaian dari amperemeter

Pada sistem pengisian-pengosongan baterai, digunakan mikrokontroler jenis AVR ATmega8535. Regulator boost untuk PL maupun PPS dikendalikan oleh sinyal pwm dengan Frekuensi clock $1250 \mathrm{kHz}$. Sedangkan frekuensi pwm sebesar $2.45 \mathrm{kHz}$ dan lebar pulsa minimum $0.8 \mu \mathrm{s}$.

Pengujian baterai seringkali memerlukan waktu lama, untuk itu diperlukan memori eksternal. Memori yang digunakan adalah IC EEPROM AT24C512 yang menggunakan komunikasi serial I2C [19]. Dengan data logger ini perangkat dapat bekerja selama 10 jam nonstop tanpa terhubung dengan komputer.

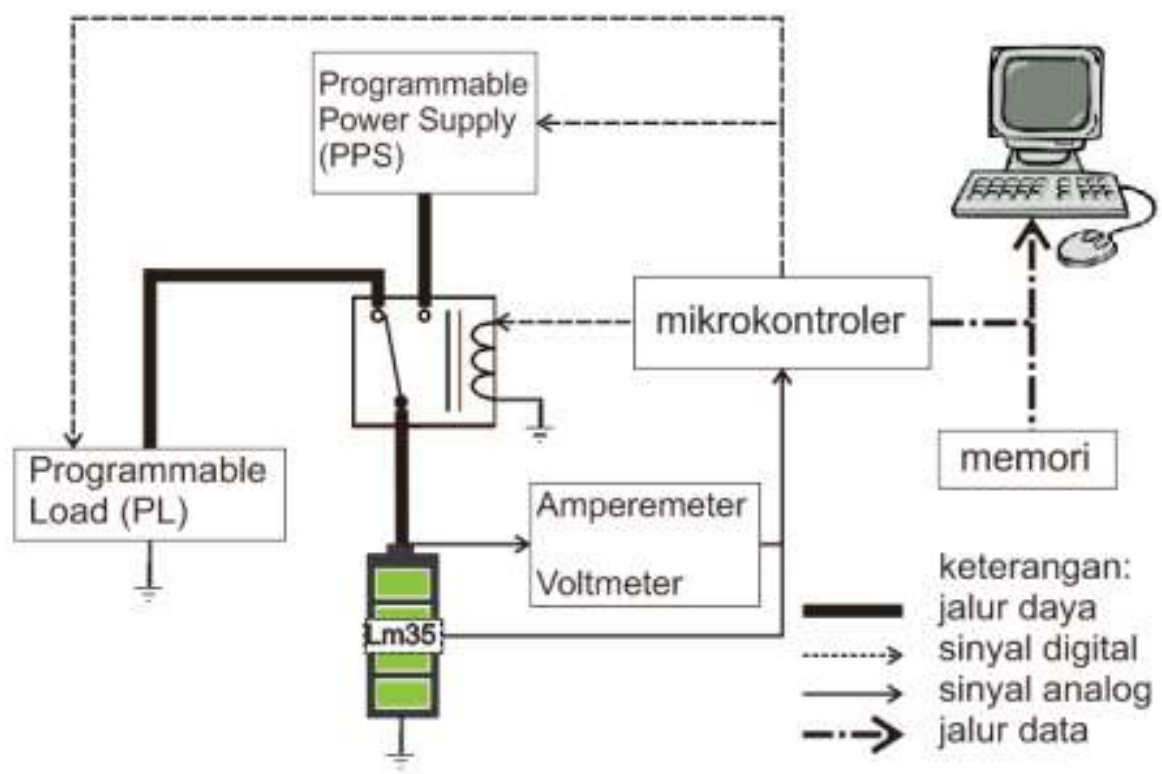

Gambar 4. Diagram skema dari sistem analisa baterai. Kutub negatif baterai yang diuji ditanahkan.

Jadi baterai tester sederhana berbasis mikrokontroler yang ditunjukkan pada gambar 1 secara lengkap diperlihatkan oleh gambar 4. PPS dan PL digunakan secara bergantian, satu untuk pengisian, lainya untuk pengosongan. BUT dihubungkan ke PPS dan PL secara bergantian. Mikrokontroler dihubungkan ke perangkat lain untuk mengendalikan PPS, PL, relay, menerima sinyal dari voltmeter dan amperemeter, dan menyimpan dan mengirimkan 
data ke komputer via USB-to-TTL converter [20]. Perlu ditambahkan sensor LM35 [21] untuk mengetahui suhu baterai selama poses berlangsung.

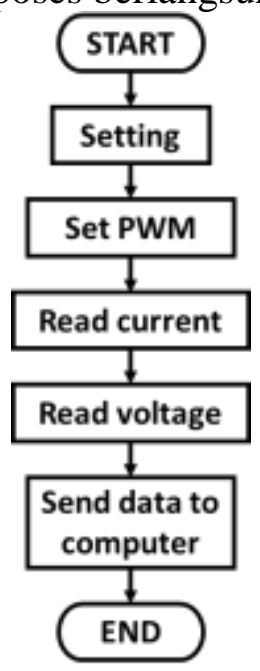

Gambar 5. Diagram alir pengukuran tegangan dan arus

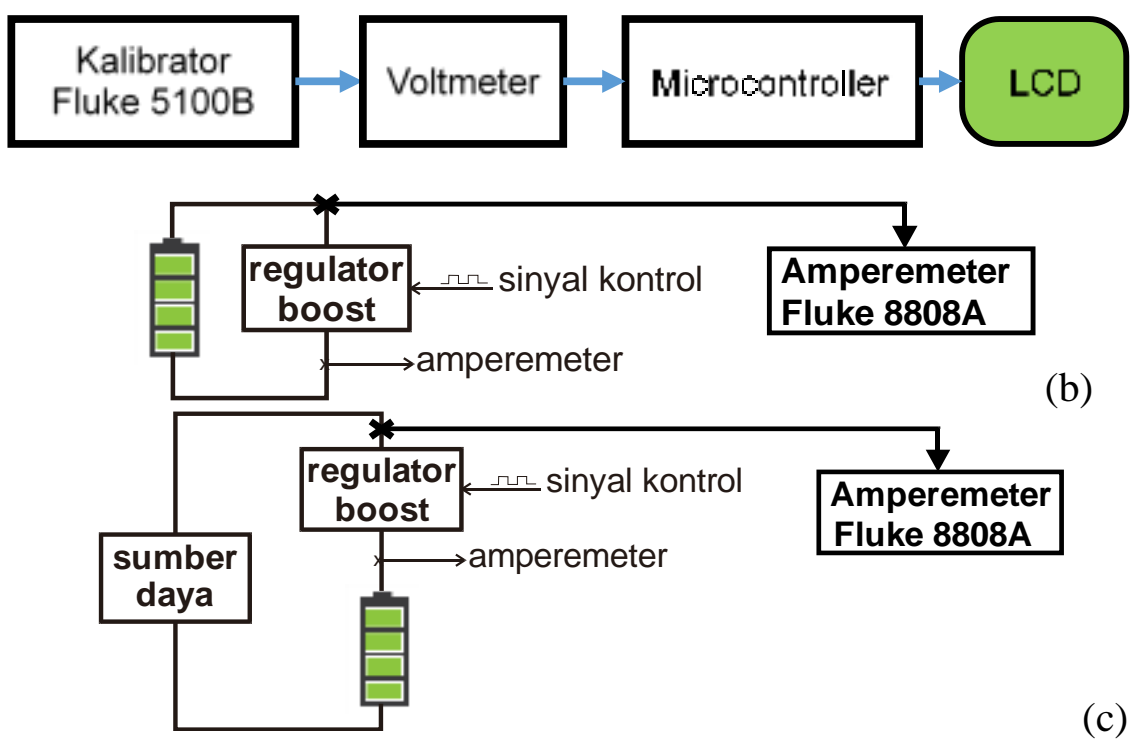

Gambar 6. skema kalibrasi (a)voltmeter (b)amperemeter pada PL (c)amperemeter pada PPS

Diagram alir karakterisasi baterai ditunjukkan oleh gambar 5. Mula-mula atur modus operasi, pengisian atau pengosongan, atur kuat arus, tegangan maksimal dan minimal. Sinyal amperemeter masuk ke adc0, suhu ke adc2 dan voltmeter ke adc6. Saat proses berlangsung, sistem menentukan lebar pulsa pwm, lalu membaca sinyal arus, tegangan dan suhu. Kemudian mngirimkan data tersebut ke koputer atau menyimpannya ke data logger.

Sebelum baterai tester digunakan untuk menganalisa baterai, perangkat perlu dikalibrasi. Proses kalibrasi dilakukan pada setiap bagian baterai tester, meliputi amperemeter, voltmeter, PL dan PPS. Fuke 8808A [22] digunakan untuk mengkalibrasi arus dan Fluke 5100B [23] untuk tegangan. Kalibrasi voltmeter ditunjukkan pada gambar 6(a), sama untuk sistem pengisian maupun pengosongan. Gambar 6(b) menunjukkan kalibrasi arus 
pada sistem pengosongan, yaitu pada bagian PL. Sedangan kalibrasi arus untuk sistem pengisian dilakukan pada bagian PPS seperti ditunjukkan gambar 6(c).

\section{PENGUJIAN BATTERY TESTER AND HASIL}

Untuk menguji baterai tester diperlukan baterai rachargable yang sudah jadi. Untuk tujuan ini digunakan baterai NiMH silinder ukuran AA dan baterai ponsel sebagai pembanding. Maka dipilih baterai LiPo BP-6M 3.7V 1100mAh dan NiMH GP-1800 1.2V $1800 \mathrm{mAh}$ yang mudah ditemukan di pasar lokal.

Baterai tester mengukur arus dan tegangan baterai, untuk itu dilakukan tiga macam pengujian, yaitu pengujian voltmeter, amperemeter dan baterai masing-masing untuk proses pengisian dan pengosongan. Pengujian voltmeter menggunakan power supply sebagai pengganti baterai, dengan meminimalkan arus. Pengujian amperemeter menggunakan cara yang sama seperti saat kalibrasi, yaitu dengan mengukur arus yang melalui regulator boost dengan amperemeter Fluke 8808A. Pengujian baterai sebenarnya (real battery) untuk melihat amperemeter dan voltmeter sekaligus, bagaimana kemampuannya jika digunakan dalam waktu yang lama.

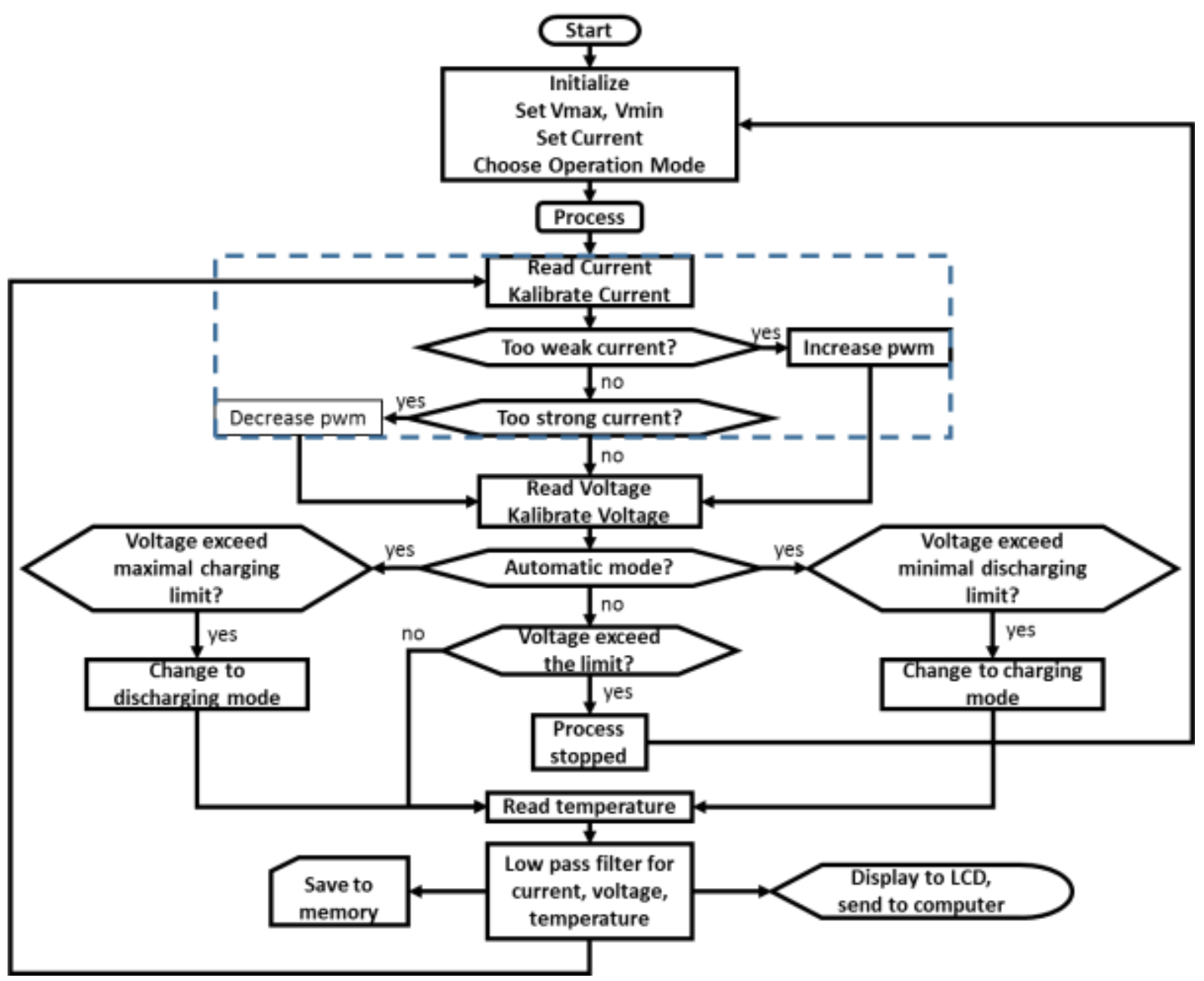

Gambar 7. Diagram alir sistem pengukuran pada mikrokontroler 
Gambar 7 menunjukkan diagram alir sistem keseluruhan yang diprogramkan pada mikrokontroler. Sebelum perangkat dihidupkan pasang baterai yang diuji (BUT) terlebih dahulu. Saat perangkat dihidupkan sistem berada di modus pengaturan. Dalam modus pengaturan diatur modus operasi, pengisian atau pengosongan, set kuat arus, tegangan minimal dan maksimal. Vmax adalah tegangan maksimum baterai dimana pengisian dihentikan jika tegangan baterai (V) telah mencapai Vmax. Vmin adalah tegangan minimal baterai, dimana pengosongan baterai dihentikan saat tegangannya telah mencapai Vmin. Set arus menentukan kuat arus konstan untuk mengisi atau mengosongkan baterai. Saat modus pengaturan selesai sistem berada pada keadaan proses, pengisian/pengosongan baterai mulai dijalankan. Saat proses dikumpulkan data arus, tegangan dan suhu. Data tersebut disimpan dalam memori setiap 4 detik, juga dikirimkan ke komputer jika terhubung. Proses berhenti dan akan kembali ke keadaan pengaturan jika tegangan telah mencapai batas maksimum atau minimum dalam modus manual. Jika proses dalam modus otomatis, jalannya proses harus dihentikan secara manual. Data dapat disimpan ke komputer selama proses berlangsung atau mengunduh data dari memori EEPROM. Data tersimpan pada komputer selanjutnya diolah dengan Microsoft Excel.

Masing-masing sistem pengisian dan pengosongan terdapat amperemeter. Amperemeter sistem pengisian dihubungkan seri dengan PPS, sedangkan sistem pengosongan dihubungkan dengan PL. Hasil pengujian amperemeter ditunjukkan bahwa Rata-rata kesalahan pengukuran 5.393478 mA dan dapat mengukur arus dari $3 \mathrm{~mA}$ hingga $2.3 \mathrm{~A}$ untuk sistem pengosongan. Saat skala terkecil $3 \mathrm{~mA}$ itu kesalahan relatif masih 86\%, kesalahan turun kurang dari 10\% pada arus yang lebih bear dari $56 \mathrm{~mA}$. Sedangkan pada sistem pengisian rata-rata kesalahan pengukuran $1.283385 \mathrm{~mA}$ dan dapat mengukur arus dari $11 \mathrm{~mA}$ hingga 2.4 A. Saat skala terkecil $11 \mathrm{~mA}$ itu kesalahan relatif masih 100\%, kesalahan turun baru turun kurang dari $10 \%$ pada skala yang lebih besar dari $80 \mathrm{~mA}$.

Voltmeter diuji dengan Power supply, voltmeter sistem pengosongan dan voltmeter standar dirangkai secara paralel. Tegangan power supply diubah-ubah dengan perubahan sekitar $5 \mathrm{mV}$. Tiap perubahan tegangan power supply dibandingkan antara yang terukur oleh voltmeter sistem pengosongan dan voltmeter standar. Hasil pengujian voltmeter menunjukkan bahwa rerata kesalahan $-2.540736364 \mathrm{mV}$ dan pengukuran cukup akurat pada tegangan 200 $\mathrm{mV}$ hingga $4.5 \mathrm{~V}$ pada sistem pengisian. Sedangkan pada sistem pengosongan rerata kesalahan $0.148823529 \mathrm{mV}$ dan dapat mengukur secara akurat pada rentang tegangan minimal $200 \mathrm{mV}$ hingga maksimal $4.5 \mathrm{~V}$.

Persen kesalahan yang dibahas disini merupakan perbandingan selisih keluaran yang terukur dengan keluaran sebenarnya terhadap keluaran terukur [24], kita definisikan persen kesalahan E sebagai berikut

$$
E=\left(\frac{V_{\text {actual }}-V_{\text {ideal }}}{V_{\text {ideal }}}\right) \times 100 \%
$$

Dimana $V_{\text {actual }}$ berupa sinyal arus pada amperemeter maupun sinyal tegangan pada voltmeter sistem. $V_{\text {ideal }}$ adalah sinyal arus atau tegangan yang terbaca kalibrator standar Fluke 8808A. 


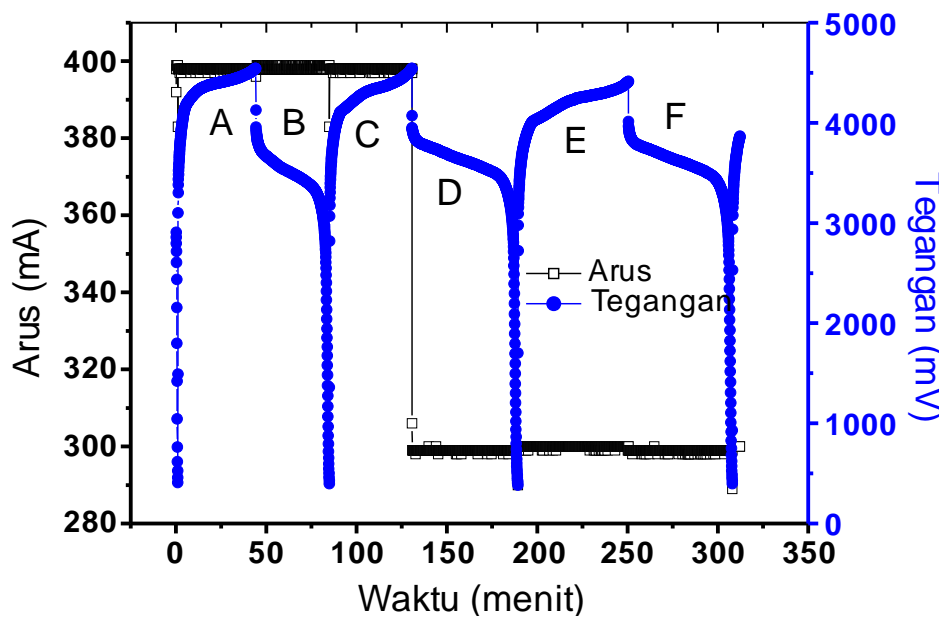

Gambar 8. Kurva pengisian-pengosongan sinambung baterai Nokia BP-6M berkapasitas 1100 mAh dengan arus 300 dan $400 \mathrm{~mA}$

Pengujian pengisian-pengosongan baterai asli dilakukan secara berurutan. Baterai dikosongkan sampai habis, kemudian diisi sampai penuh. Data pengujian baterai Li-Po BP$6 \mathrm{M}$ diperlihatkan pada gambar 8. Sebelum diuji bms internal baterai dilepas terlebih dahulu untuk meniadakan pengaruh sirkuit pelindung. Sistem telah dapat menghasilkan arus konstan dan tegangan baterai membentuk kurva sesuai pola pengisian dan pengosongan bateri pada umumnya [12] [25]. Gambar 9 menunjukkan perilaku suhu selama pengujian berlangsung. Terlihat ada hubungan antara kurva I-V dengan suhu, terjadi kenaikan suhu pada titik ekstrim, yaitu saat muatan baterai hampir penuh dan saat hampir habis. Namun untuk membahasnya perlu penelitian lebih lanjut yang menghilangkan pengaruh suhu lingkungan.

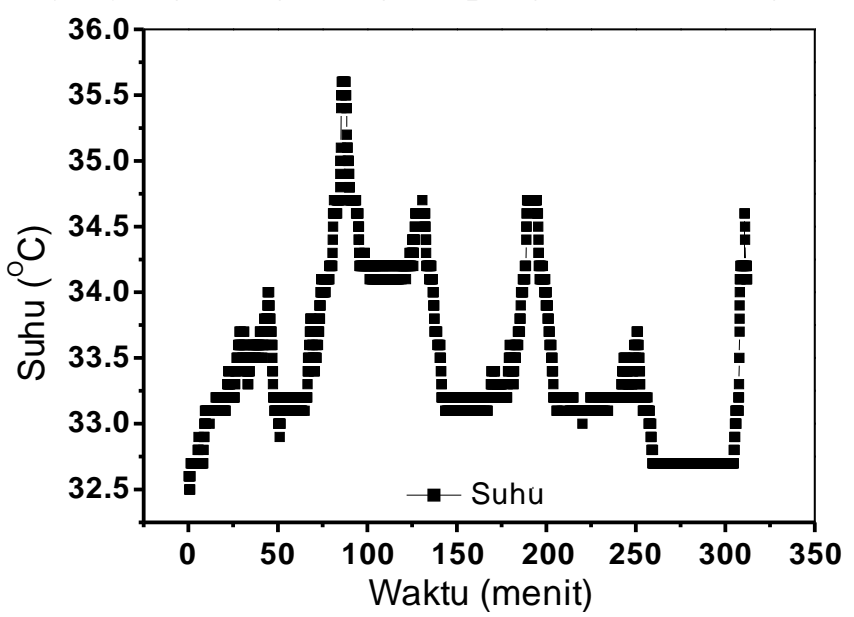

Gambar 9. Grafik fluktuasi suhu baterai selama proses pengisian-pengosongan berlangsung

Pengolahan data lebih lanjut dapat dilakukan ekstraksi dan normalisasi. Baru setelah itu dapat ditentukan kapasitas muatan dan kapasitas energi. Kapasitas muatan baterai dapat ditentukan dengan rumus

$Q=\sum_{t} I(t) \Delta t$

dimana I adalah kuat arus pada saat t selama selang waktu $\Delta$ t. Disini kapasitas didefinisikan sebagai banyaknya muatan atau energi yang terbuang saat pengosongan atau banyaknya 
muatan atau energi yang ditambahkan pada baterai saat pengisian. Maka kapasitas energi dihitung dengan rumus

$W=\sum_{t} I(t) V(t) \Delta t$

dimana $\mathrm{V}$ adalah tegangan pada saat $\mathrm{t}$ selama $\Delta \mathrm{t}$.

Proses ekstraksi dimulai dengan memisahkan bagian mana pengisian, mana bagian pengosongan. Setiap proses dapat ditentukan dari trend perubahan tegangannya, tegangan pengisian cenderung naik dan sebaliknya untuk pengosongan, cenderung turun. Setelah dipisahkan, dilakukan penyesuaian tegangan kutub menjadi potensial sel, sesuai rumus $V=E \pm I R$

dengan $\mathrm{V}$ adalah tegangan kutub, $\mathrm{E}$ adalah potensial sel, I adalah arus dan $\mathrm{R}$ adalah hambatan dalam. Tanda + untuk proses pengisian dan tanda - untuk proses pengosongan. Perlu diasumsikan potensial sel rerata pada baterai adalah $3.7 \mathrm{v}$, sesuai yang tertulis pada kemasannya. Perubahan potensial sel setiap waktu dapat ditentukan dengan persamaan $E=V+I\left(\frac{E_{S}-V_{S}}{I_{S}}\right)$

Dimana E adalah potensial sel, $\mathrm{V}$ adalah teganagan kutub, I adalah arus pengisian atau pengosongan, Is dan $\mathrm{V}_{\mathrm{S}}$ adalah arus dan tegangan tegangan kutub paling stabil, dan $\mathrm{E}_{\mathrm{S}}$ adalah potensial sel paling stabil atau tegangan nominal baterai.

Hasil ekstraksi dapat dilihat pada gambar 10. Hal unik pada proses pengisian dan pengosongan adalah pola tegangannya yang mirip dengan pola pengisian-pengosongan kapasitor, bersifat transien naik atau transien turun, namun ia tidak bisa didekati dengan rumus sederhana. Pada grafik terlihat dibutuhkan waktu pengisian sedikit lebih lama daripada saat pengosongan. Idealnya waktu yang dibutuhkan untuk pengisian sama dengan pengosongan karena digunakan arus yang sama besar, namun kapasitas pengisian selalu lebih besar daripada kapasitas pengosongan. Oleh sebab itu telah disepakati bahwa kapasitas nominal baterai adalah kapasitas pengosongan.

Normalisasi diperlukan ketika kita ingin membandingkan pola pengisian/pengosongan dengan beberapa arus yang berbeda. Satuan waktu pada gambar 10 tak dapat digunakan karena akan terlihat pola yang tak seimbang. Diperlukan satuan yang sama untuk arus berbeda, yaitu kapasitas. Grafik yang telah ternormalisasi ditunjukkan pada gambar 11.

Dengan mengetahui pola pengisian atau pengosongan untuk beberapa tingkat arus, dapat diketahui hambatan dalam pada kapasitas tertentu secara lebih teliti. Asumsikan bahwa pada kapasitas yang sama, potensial sel sama, begitu juga degan hambatan dalam. Namun hambatan dalam berubah seiring dengan perubahan banyaknya muatan pada baterai, $R=R(c)$. Untuk itu gunakan rumus

$$
R(c)=\frac{d V}{d I}=\frac{\Delta V(I, c)}{\Delta I}= \pm \frac{V\left(I_{1}, c\right)-V\left(I_{2}, c\right)}{I_{1}-I_{2}}
$$

dengan $\mathrm{I}_{2}<\mathrm{I}_{1}$, tanda (+) untuk pengisian dan (-) untuk pengosongan. 

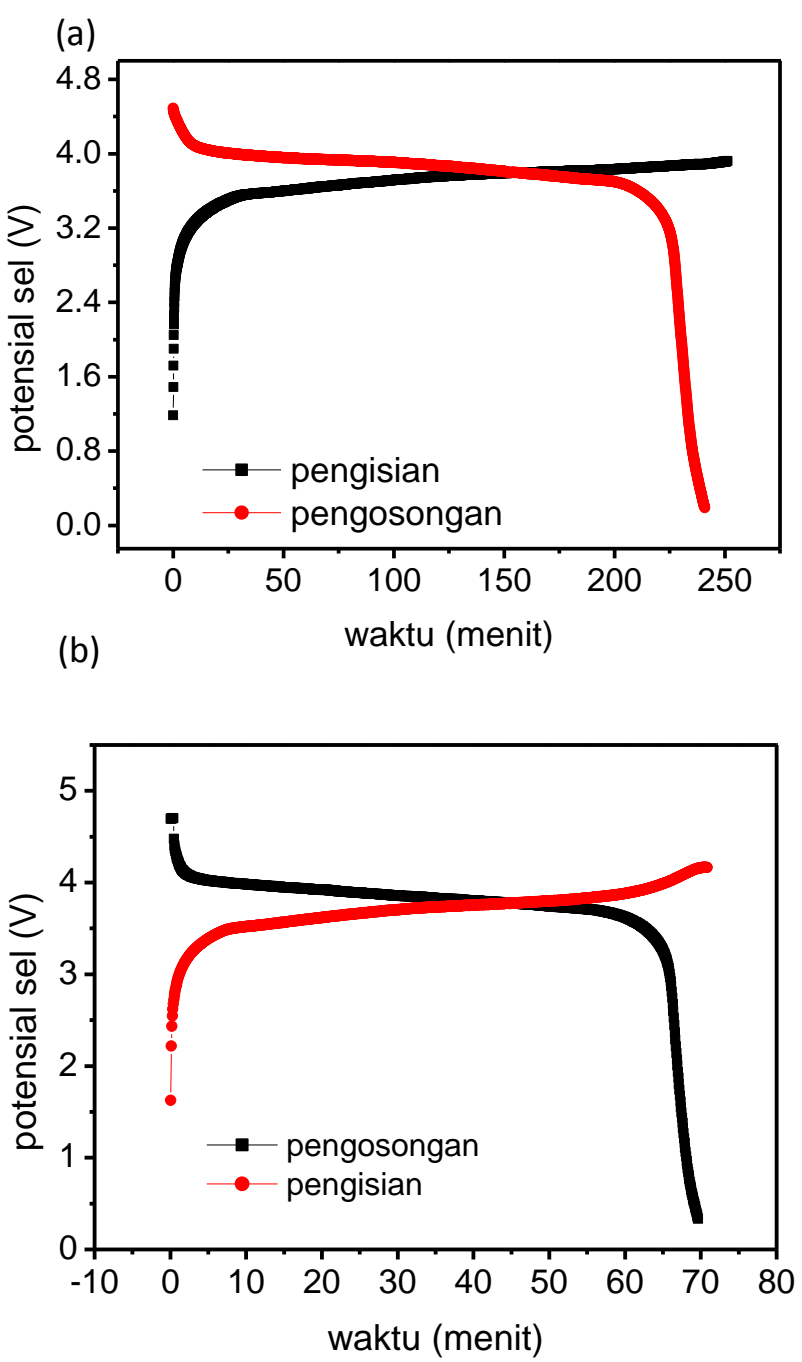

Gambar 10. Grafik pengisian-pengosongan baterai LiPo dengan arus (a) 0.09C dan (b) 0.27C

Spesifikasi baterai BP-6M menyebutkan bahwa kapasitasnya 1100 mAh, namun hasil pengujian menunjukkan kapasitas terhitung kurang dari $400 \mathrm{mAh}$. Belum diketahui apakah kesalahan ini disebabkan keterbatasan alat atau masalah baterai itu sendiri sehingga kita mengujinya dengan baterai lain. Untuk itu digunakan baterai NiMH 1.2 volt, 1800mAh.

Baterai NiMH GP-1800 diuji dengan cara yang sama dengan LiPo. Setelah ekstraksi dan normalisasi didapatkan data yang ditunjukkan pada gambar 12. Kapasitas terhitung sekitar 2000mAh, selisih $11 \%$ dari kapasitas yang tercantum pada kemasan, lumayan akurat untuk peralatan uji yang sederhana. Dibutuhkan tegangan pengisian $2.4 \mathrm{~V}$ dengan arus $0.4 \mathrm{C}$ untuk baterai $\mathrm{NiMH}$, dua kali lipat dari tegangan nominal, $0.2 \mathrm{~V}$. Mungkin masalah inilah yang terjadi pada baterai lithium, dibutuhkan setidaknya tegangan pengisian $7.4 \mathrm{~V}$ untuk tegangan nominal $3.7 \mathrm{~V}$, sedangkan baterai analizer hanya bisa sampai 4.5 V. Tegangan baterai NiMH terlihat tidak stabil, terutama saat pengisian, dan cukup stabil untuk LiPo. Itulah kenapa peralatan elektronik saat ini lebih banyak menggunakan baterai lithium dari pada NiMH. 

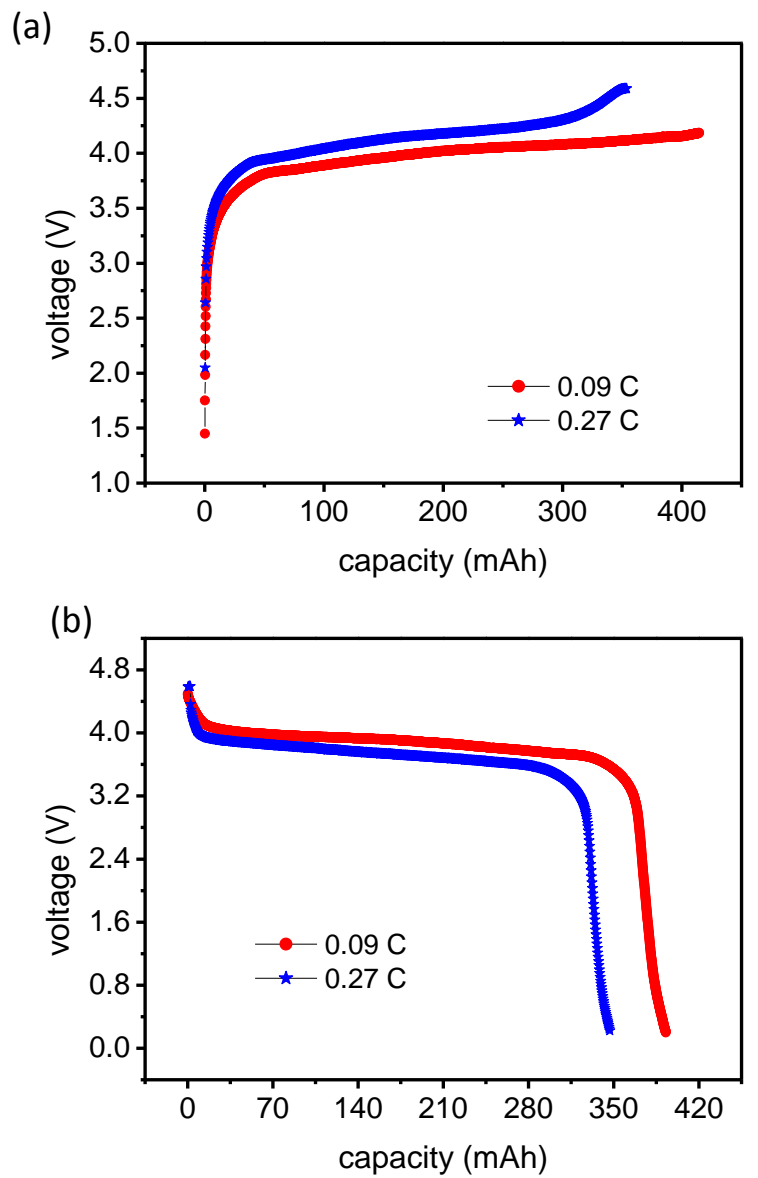

Gambar 11. grafik ternormalisasi dari (a) pengisian (b) pengosongan baterai LiPo

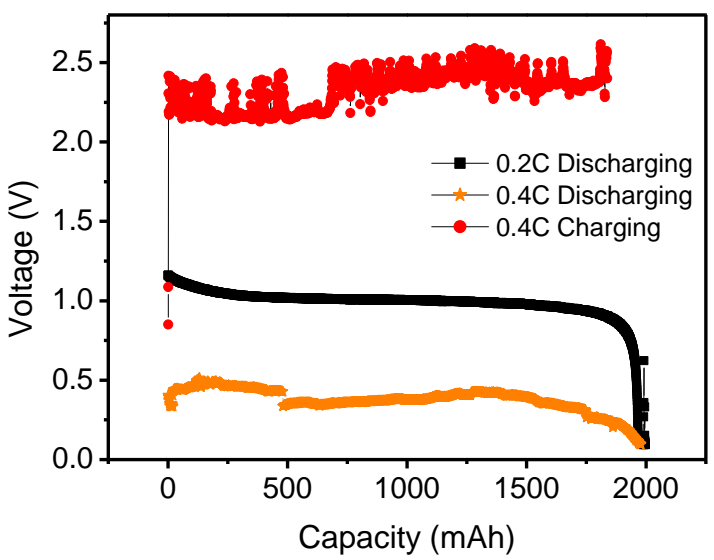

Gambar 12. karakteristik pengisian-pengosongan baterai NiMH GP-1800

\section{KESIMPULAN}

Telah dikembangkan baterai tester sederhana berbasis mikrokontroler ATMega 8535. Sistem terdiri dari programmable power supply (PPS), programmable load (PL), amperemeter, voltmeter, komputer dan seluruhan bagian dikendalikan oleh mikrokontroler. Sistem telah dikalibrasi dan digunakan untuk menguji baterai komersial LiPo dan NiMH. Kurva pengisian dan pengosongan telah sesuai dengan pengujian baterai dengan arus tetap 
pada umumnya. Kapasitas baterai terhitung telah sesuai dengan datasheet kecuali untuk tegangan pengisian yang kurang dari $5 \mathrm{~V}$.

\section{DAFTAR PUSTAKA}

[1] Q. Jieting, C. Rujun, T. Bo dan W. Honglan, "Multi-Channel High Precission Battery Test System," dalam The Eight International Conference on Electronic Measurement and Instruments, Changsa, 2007.

[2] R. Xiong, H. He, H. Guo dan Y. Ding, "Modeling for Lithium-Ion Battery used in Electric Vehicles," Procedia Engineering, no. 15, p. 2869 - 2874, 2011.

[3] D. Riu, M. Montaru dan Y. Bultel, "Time domain simulation of Li-ion batteries using non-integer order equivalent electrical circuit," Commun Nonlinear Sci Numer Simulat, no. 18, p. 1454-1462, 2013.

[4] T. Tsujikawa, K. Yabuta, M. Arakawa dan K. Hayashi, "Safety of large-capacity lithium-ion battery and evaluation of battery system for telecommunications," Journal of Power Sources, no. 13, 2013.

[5] J. Hanny H Tumbelaka, “Alat Uji Baterai 12V, 60AH Secara Elektronis," Jurnal Teknik Elektro, vol. 1, pp. 9-13, Maret 2001.

[6] L. Liu, F. Tian, M. Zhou, H. Guo dan X. Wang, "Aqueous rechargeable lithium battery based on polyaniline and LiMn2O4 with good cycling performance," Electrochimica Acta, no. 70, p. 360-364, 2012.

[7] T. Mayer, D. Kreyenberg, J. Wind dan . F. Braun, "Feasibility study of 2020 target costs for PEM fuel cells and lithium-ion batteries: A two-factor experience curve approach," International journal of hydrogen energy, no. 37, pp. 14463-14474, 2012.

[8] M.-K. Song, S. Park, F. M. Alamgir, J. Cho dan M. Liu, "Nanostructured electrodes for lithium-ion and lithium-air batteries: the latest developments, challenges, and perspectives," Materials Science and Engineering: R: Reports, pp. 203-252, 2011.

[9] R. Thirunakaran, R. Ravikumar, S. Gopukumar dan A. Sivashanmugam, "Electrochemical evaluation of dual-doped LiMn2O4 spinels synthesized via coprecipitation method as cathode material for lithium rechargeable batteries," Journal of Alloys and Compounds, no. 556, p. 266-273, 2013.

[10] O. Toprakci, H. A. Toprakci, . L. Ji dan X. Zhang, "Fabrication and Electrochemical Characteristics of LiFePO4 Powders for Lithium-Ion Batteries," KONA Powder and Particle Journal, vol. 28, pp. 50-73, 2011.

[11] G. Mulder, N. Omar, S. Pauwelsd, M. Meeus, F. Leemans, B. Verbrugge, W. . D. Nijs, P. V. d. Bossche, D. Six dan J. V. Mierlo, "Comparison of commercial battery cells in relation to material properties," Electrochimica Acta, no. 87, p. 473- 488, 2013.

[12] H. Chuangfeng, L. Pingan dan J. Xueyan, "Measurement and analysis for lithium battery of high-rate discharge performance," Procedia Engineering, no. 15, p. 2619 2623, 2011.

[13] D. Zhang, "Studies on Capacity Fade of Lithium-Ion Batteries," Journal of Power Source, pp. 122-129, 2000. 
[14] M. . M. Munir, S. . N. Wahid, F. Iskandar dan Khairurrijal, “A System for Characterizing Batteries and Their Charging-Discharging Properties," Applied Mechanics and Materials, vol. 771, pp. 96-99, 2015.

[15] Atmel Corporation, ATmega8535(L), San Jose, CA: Atmel Corporation, 2006.

[16] M. Jain, M. Daniele dan P. K. Jain, “A Bidirectional DC-DC Converter Topology for Low Power Application," IEEE TRANSACTIONS ON POWER ELECTRONICS, vol. 15, no. 4, pp. 595-606, 2000.

[17] I. Ibrahim, A. Omar dan Z. Hussain, "Control Strategy of Power Converter System in the Dual-power PV-grid System Energy Utilizing Cascaded Multilevel Inverter," dalam IEEE 8th Conference on Industrial Electronics and Applications (ICIEA), MARA, 2013.

[18] ON Semiconductor, LM324/D, Denver, Colorado: Semiconductor Components Industries, 2002.

[19] Atmel, AT24C512, San Jose: Atmel Corporation, 2005.

[20] Depok Instruments, “DI-USB to Serial TTL,” Depok Instruments, Depok, 2011.

[21] National Semiconductor, "LM 35 Precision Centigrade Temperature Sensors," November 2000. [Online]. Available: www.national.com.

[22] Fluke, 8808A Digital Multimeter Users Manual, Everet, WA: Fluke Corporation, 2007.

[23] Fluke, 5100B series calibrators instruction manual, Everet, WA: Fluke Corporation, 1992.

[24] Khairurrijal, M. Abdullah, A. Suhendi, M. M. Munir dan A. Surachman, “A simple microcontroller-based current electrometer made from LOG112 and C8051F006 for measuring current in metal-oxide-semiconductor devices," Measurement Science and Technology, no. 18, pp. 3019-3024, 2007.

[25] Sony Corporation, Lithium Ion Rechargeable Batteries Technical Handbook, Tokyo: Osaki West Technology Center, 2013. 